Estructura de la población, esfuerzo y rendimiento de tinte del caracol Plicopurpura pansa (Gould, 1853) en el Pacífico mexicano

\title{
Population structure, effort and dye yielding of the snail Plicopurpura pansa (Gould, 1853) in the Mexican Pacific
}

\author{
Jesús Emilio Michel-Morfín ${ }^{1 *}$ \\ Ernesto A. Chávez ${ }^{2}$ \\ Lourdes González ${ }^{1}$
}

\author{
${ }^{1}$ Departamento de Estudios para el Desarrollo Sustentable de Zonas Costeras \\ Centro Universitario de la Costa Sur \\ Universidad de Guadalajara \\ Gómez Farías 82 \\ San Patricio-Melaque, CP 48980, México \\ *E-mail:michel@costera.melaque.udg.mx \\ ${ }^{2}$ Centro Interdisciplinario de Ciencias Marinas - IPN \\ Av. IPN s/n, Playa El Conchalito \\ La Paz, CP 23000, México \\ Recibido en agosto de 2001; aceptado en julio de 2002
}

\section{Resumen}

El caracol del tinte Plicopurpura pansa, especie bien representada en la zona intermareal rocosa del Pacífico tropical americano, es considerado un recurso pesquero potencial por el tinte que de él se obtiene y estuvo sujeto a explotación en algunos estados del Pacífico mexicano durante la década de los años ochenta. Con el objeto de evaluar el estado actual de sus poblaciones y conocer algunos aspectos de su dinámica, y rendimiento del tinte, se llevó a cabo una serie de muestreos en 12 playas rocosas de Baja California Sur, Jalisco, Oaxaca e Isla Socorro, México. Se encontró una proporción de sexos cercana a 1:1, la densidad presenta valores entre 0.47 y 1.24 caracoles $\mathrm{m}^{-2}$ y se observó una relación entre la talla promedio y el volumen de tinte obtenido. Por medio de entrevistas con los teñidores mixtecos de la costa de Oaxaca y de ordeñas sobre madejas de hilo de algodón, se calculó el rendimiento por unidad de área, estimándose valores cercanos a los 2.5 litros de tinte semana/pescador, lo que equivale a teñir 2.2 madejas/semana/pescador.

Palabras clave: Moluscos, caracol del tinte, Plicopurpura pansa, rendimiento, tintes naturales.

\begin{abstract}
The purple snail (Plicopurpura pansa) is a conspicuous rocky-shore species in the tidal zone of the American tropical Pacific. It is considered a potential resource because of the dye it produces. In the 1980s the snail underwent exploitation in the Pacific coast of Mexico. Samples in 12 rocky shores of the Baja California Sur, Jalisco and Oaxaca states, and the Socorro Island were made, finding a sexual ratio near to $1: 1$, densities ranging from 0.47 to 1.24 snails $\mathrm{m}^{-2}$ and a relation between dye yield and specimens' length. By interviews with the Mixteco people in Oaxaca and milking of the snails over cotton skeins, dye yield was calculated as 2.5 liters of dye per week/fisherman or 2.2 skeins per week/fisherman.
\end{abstract}

Key words: Molluscs, purple snail, Plicopurpura pansa, yield, natural dyes.

\section{Introducción}

El caracol púrpura o del tinte Plicopurpura pansa (Gould, 1853; Sinónimo: Purpura pansa), es una especie conspicua de la zona intermareal del Pacífico tropical oriental (Keen, 1971). Los caracoles se encuentran comúnmente fijos a sustratos rocosos expuestos al oleaje en la zona intermareal. Su máxima

\section{Introduction}

The purple snail Plicopurpura pansa (Gould, 1853; Synonim: Purpura pansa) is a conspicuous species in the intertidal zone of the Eastern tropical Pacific (Keen, 1971). Snails are often attached to wave-exposed rocky substrata in the intertidal zone and their maximum abundance is observed in the 
abundancia se observa en la franja superior y media del nivel mesolitoral, donde muestran ciclos de actividad de períodos cortos relacionados con los cambios diurnos y del nivel de mareas (León-Álvarez, 1989, Avilés et al., 1990). Son depredadores activos. Se alimentan de invertebrados intermareales entre los que destacan los poliplacóforos (Chiton spp.) y otras especies de gasterópodos como Nerita spp. y Littorina spp. (Turok et al., 1988; Castillo-Rodríguez y Amezcua-Linares, 1992).

Al igual que otras especies de los géneros Purpura, Plicopurpura, Murex o Thais, este caracol ha sido utilizado para la obtención de un tinte de color púrpura muy apreciado. $\mathrm{Su}$ característica distintiva con respecto a otras especies de moluscos productores, en los cuales es necesario romper la concha del animal y extraer la glándula que contiene el tinte, es que en $P$. pansa la extracción se realiza estimulando el pie y el opérculo del animal, sin requerirse el sacrificio de los organismos. De acuerdo con Michel-Morfín y Chávez (2000), es posible obtener ordeñas sucesivas cada 21 días sin detrimento de la población.

En la década de los ochenta, en las costas del Pacífico mexicano, el caracol púrpura fue sujeto de una redituable explotación comercial por parte de una compañía japonesa, para teñir kimonos de seda muy apreciados en la cultura oriental. Sin embargo, dado que esta actividad se realizaba procurando obtener los mayores volúmenes de tinte, no se consideraba el tiempo transcurrido entre una ordeña y la siguiente, lo que ocasionó alta mortalidad por el mal manejo (Turok et al., 1988). Esta explotación terminó en 1988, cuando la especie se declaró sujeta a protección especial (Anónimo, 1988; Anónimo, 1994). En la actualidad su tinte solo es utilizado por teñidores mixtecos en la costa de Oaxaca, quienes lo emplean desde tiempos precolombinos para la tinción de vestimentas de uso tradicional (fig. 1) (Turok, 1996).

De los trabajos realizados acerca del caracol del tinte en el Pacífico mexicano, destacan los de Turok et al. (1988) y Turok (1996) que abordan aspectos antropológicos sobre la tradición del uso del tinte de esta especie (fig. 1). Acevedo y Hernández (1988), Álvarez (1989), Acevedo et al. (1990), CastilloRodríguez y Amezcua-Linares (1992), Holguín (1993), RíosJara et al. (1994), Acevedo (1995), Michel-Morfín (2000), Michel-Morfín y Chávez (2000) y Michel-Morfín et al. (2000) han realizado diversos estudios de tipo biológico-pesquero relativos al aprovechamiento del recurso.

El objetivo del presente estudio es el de contar con información sobre el estado actual de las poblaciones del caracol en diversas localidades de la costa del Pacífico mexicano, además de obtener estimaciones sobre el rendimiento del tinte y su uso actual. Esta información será utilizada para el desarrollo de un modelo de rendimiento pesquero actualmente en desarrollo. Con este fin se realizaron una serie de muestreos de caracoles y colectas de tinte en costas rocosas de los estados de Baja California Sur, Jalisco, Oaxaca y en la Isla Socorro del Archipiélago Revillagigedo. upper and middle fringe of the mesolitoral level, where they exhibit short-period activity cycles related to diurnal changes and tidal level (León-Álvarez, 1989; Avilés et al., 1990). They are active predators feeding on intertidal invertebrates among which the polyplacophors (Chiton spp.) and other species of gastropods as Nerita spp. and Littorina spp. outstand (Turok et al., 1998; Castillo-Rodríguez and Amezcua-Linares, 1992).

As other species of the genuses Purpura, Plicopurpura, Murex or Thais, this snail has been used to get a highly appreciated purple dye. Distinctively from other dye-yielding mollusk species in which breaking the shell and extracting the dye gland is necessary, in P. pansa the extraction is done by stimulating the animal's foot and operculum, without the need of sacrificing any organism. According to Michel-Morfín and Chávez (2000), it is possible to have successive milks every 21 days without any damage to the population.

In the 1980s, in the Mexican Pacific coast, the purple snail was subject to a profitable exploitation by a Japanese company in order to dye silk kimonos that were highly appreciated in the Eastern culture. However, given that this activity was done trying to get the highest volumes of dye, the time between milkings was not considered, causing a high mortality due to the mismanagement of the resource (Turok et al., 1988). This exploitation ended in 1988, when this species was declared under special protection (Anonimous, 1988; Anonimous, 1994). Currently, only the Mixteco people in the coast of the Mexican state of Oaxaca use the snail dye from whom it has been used since pre-colonial times to dye their traditional clothing (fig. 1) (Turok, 1996).

From works done about the purple snail in the Mexican Pacific, outstand those by Turok et al. (1988) and Turok (1996) that deal with anthropological aspects of the traditional use of this species' dye (fig. 1). Acevedo and Hernández (1988), Álvarez (1989), Acevedo et al. (1990), Castillo-Rodríguez and Amezcua-Linares (1992), Holguín (1993), Ríos-Jara et al. (1994), Acevedo (1995), Michel-Morfín (2000), MichelMorfín and Chávez (2000) and Michel-Morfín et al. (2000) have done several biological-fishery studies related to the use of this resource.

The aim of this study is to count with information about the current status of the snail's populations in several localities of the Mexican Pacific coast, besides obtaining estimations about the dye yield and its present use. This information will be used for the development of a fishery-yielding model that is under development. With this purpose, a series of samplings of snails and dye collects were done in rocky shores of the states of Baja California Sur, Jalisco, Oaxaca and the Socorro Island in the Revillagigedo Archipelago.

\section{Material and methods}

\section{Sampling sites}

In Baja California Sur (BCS), a sampling site was considered in the Pacific coast which was sampled at two different places, and another one in the the Gulf of California coast. The 

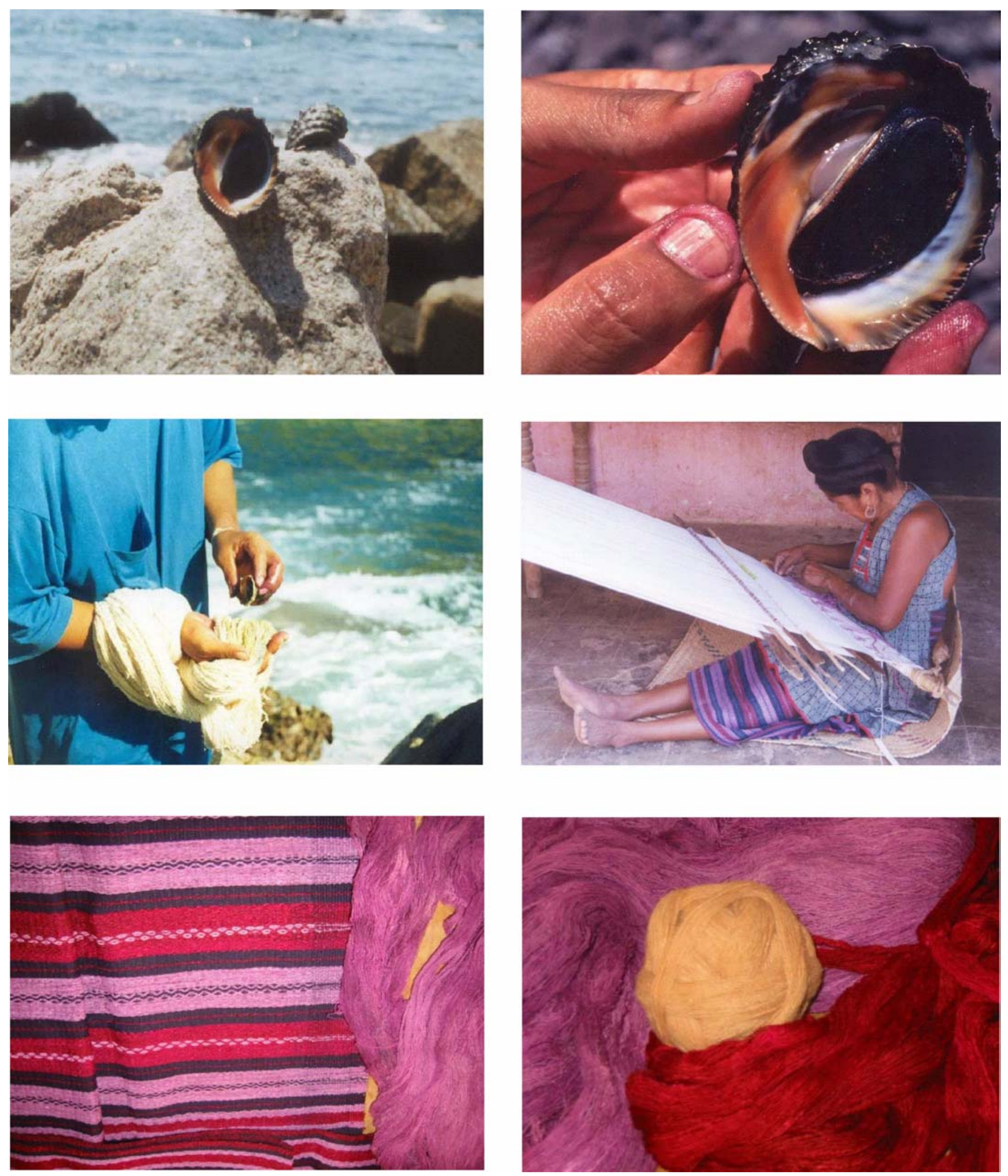

Figura 1. Aprovechamiento del tinte de Plicopurpura pansa

Figure 1. Exploitation and use of the Plicopurpura pansa dye. 


\section{Materiales y métodos}

Sitios de muestreo

En Baja California Sur (BCS) se consideró un sitio de muestreo en la costa del Pacífico, el cual fue muestreado en dos lugares diferentes, y otro en la costa del Golfo de California. Los puntos considerados fueron Punta Pescadero en la costa occidental del Estado (parte norte y sur) y la porción rocosa de la playa de Los Frailes, en la costa del Golfo de California (fig. 2).

Se determinaron dos puntos de muestreo en la costa sur del estado de Jalisco: Playa Dorada y Playa Carrizalillos, ambas ubicadas dentro de la Bahía de Navidad.

Para la Isla Socorro, en el Archipiélago Revillagigedo (Colima), se determinaron cinco puntos de muestreo, eligiendo sitios cercanos a la base militar y por lo tanto accesibles por tierra, o bien cercanos a lugares de desembarque. Los sitios fueron, de sur a norte: Bahía Binners, Bahía Vargas-Lozano, Bahía Braithwaite, Bahía Grayson y Bahía Blanca.

En la costa de Oaxaca se hicieron muestreos en las costas rocosas de las Bahías de Huatulco y en la zona cercana a Puerto Angel, áreas donde normalmente realizan sus recorridos de ordeña los teñidores de la población de Pinotepa de Don Luis, Oaxaca. Las zonas consideradas fueron de sur a norte: Copal, Jicaral, Isla San Agustín, La Tijera y El Ahorcado.

Todos los sitios de muestreo son playas con sustrato rocoso, de tipo ígneo, de alta dinámica y en zonas expuestas al embate de las olas, condiciones que favorecen la presencia de caracoles $P$. pansa. Los muestreos se realizaron en Jalisco e Isla Socorro en junio de 1997; en BCS durante agosto de 1997 (Punta Pescadero, parte norte), marzo de 1998 (Los Frailes) y mayo de 1998 (Punta Pescadero en su parte sur); y en Oaxaca, durante noviembre de 1998.

\section{Trabajo de campo}

En cada punto de muestreo se hizo un transecto de $50 \mathrm{~m}$ de largo por $2 \mathrm{~m}$ de ancho $\left(100 \mathrm{~m}^{2}\right)$, paralelo a la línea de costa, ubicado en las zonas mesolitorales, superior o media, que son las zonas donde principalmente se distribuye el caracol (LeónÁlvarez, 1989), dependiendo del nivel de la marea en el momento del muestreo. Sobre dicho transecto, se realizó un censo de la zona delimitada y se recabó información de todos los caracoles $P$. pansa.

Simultáneamente a la recolecta, y con el objeto de evaluar la producción de tinte, se indujo manualmente la expulsión del tinte en los caracoles, despegando cuidadosamente el animal de la roca, soplando sobre el opérculo y estimulando ligeramente el pie del animal con el dedo pulgar. El tinte obtenido fue depositado en un envase de plástico y posteriormente fue medido. A fin de obtener una estimación de los rendimientos del tinte con relación a una medida de esfuerzo, se determinó el tiempo transcurrido, el número total de caracoles y el volumen sites taken into consideration were Punta Pescadero in the State's West coast (northern and southern parts) and the rocky portion of the Los Frailes Beach, in the coast of the Gulf of California (fig. 2).

Two sampling sites were determined for the southern coast of Jalisco: La Dorada Beach and Carrizalillos Beach, both located within the Navidad Bay.

For the Socorro Island in the Revillagigedo Archipelago (Colima), five sampling sites were determined, choosing places nearby the military base and therefore accessible by land or places close to accessible places by sea. These sites were from South to North: Binners Bay, Vargas-Lozano Bay, Braithwaite Bay, Grayson Bay and Blanca Bay.

In the coast of Oaxaca samplings were done in the rocky shores of the Huatulco Bays and in the nearby zone to Puerto Angel, areas to where the dyers from the Pinotepa de Don Luis, Oaxaca usually make trips for milking. The zones considered South to North: Copal, Jicaral, San Agustín Island, La Tijera and El Ahorcado.

All the sampling sites are beaches with substratum formed mainly by igneous rocks, highly dynamic and exposed to the waves, conditions that favor the presence of $P$. pansa snails. Samplings in Jalisco and the Socorro Island were done in June 1997; in BCS during August 1997 (Punta Pescadero, northern side), March 1998 (Los Frailes) and May 1998 (Punta Pescadero, southern side), and in Oaxaca during November 1998.

\section{Fieldwork}

A 50-m-long and 2-m-wide transect $\left(100 \mathrm{~m}^{2}\right)$ parallel to the coast was covered in each sampling site, located in the upper or the middle mesolittoral areas where the snail commonly distributes (León-Álvarez, 1989), depending on the tidal level at sampling. A census was done within the delimited area obtaining by this means information of all P. pansa snails.

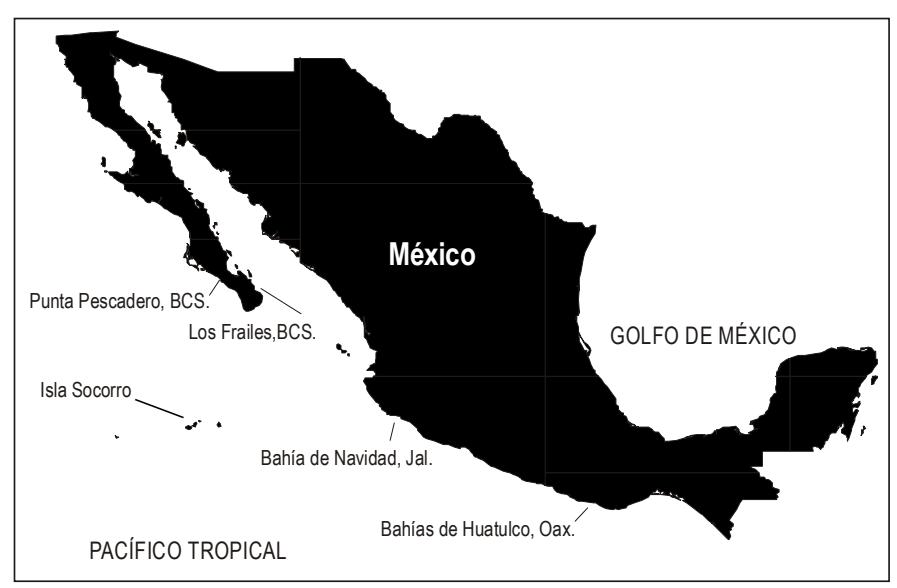

Figura 2. Áreas de estudio en el Pacífico mexicano. Figure 2. Study areas in the Mexican Pacific. 
total de tinte obtenido en cada transecto. La pendiente de la playa se determinó por medio de un clinómetro.

Una vez realizada la recolecta de los caracoles, los ejemplares fueron medidos en su longitud total (desde el ápice hasta el final del canal sifonal). El sexo de cada organismo fue determinado observando la presencia de pene $u$ orificio gonadal logrando la salida de la parte blanda del organismo, al sacudir el caracol. Una vez realizado este proceso, los caracoles se liberaron en la misma zona de donde fueron recolectados, en áreas protegidas del embate de las olas y a la sombra.

Las actividades de campo se efectuaron en todos los casos entre las 8:00 y las 16:00 horas, buscando realizar las recolectas en los períodos de marea baja.

El anterior procedimiento se efectuó en todas las playas, con excepción de los puntos de muestreo de la costa de Oaxaca. En este caso, se realizó un recorrido conjuntamente con un pescador de la costa, quien se dedica a la tinción de madejas. A partir de una madeja sin teñir, de hilo de algodón y con un peso de $285 \mathrm{~g}$, se contaron todos los caracoles que se utilizaron para teñir dicha madeja, así como el tiempo y el área de costa recorrida por el teñidor. Los datos biológicos de los caracoles se obtuvieron solamente de las playas de Copal, Jicaral e Isla San Agustín, en las Bahías de Huatulco.

Además, se realizó una serie de entrevistas a los teñidores y tejedoras de la comunidad mixteca de Pinotepa de Don Luis, Oaxaca con el fin de determinar el uso actual de tinte del caracol para la confección de vestimentas tradicionales.

\section{Resultados}

\section{Estructura poblacional}

En la tabla 1 se presentan los resultados de la densidad relativa y la proporción sexual de cada uno de los sitios de muestreo considerados en la costa del Pacífico mexicano. En general, la densidad relativa promedio es de 0.86 caracoles $\mathrm{m}^{-2}$ (desviación estandar $=0.26$ ). El valor más alto de densidad relativa se registró en Los Frailes, BCS, con 1.24 caracoles $\mathrm{m}^{-2}$. El valor más bajo se presentó en Bahía Blanca, Isla Socorro, con 0.47 caracoles $\mathrm{m}^{-2}$. La proporción sexual es cercana a una hembra por cada macho. La prueba de Chi-cuadrada indica que sólo en Punta Pescadero, en sus partes norte y sur, se presentan diferencias significativas a ésta proporción $(P<0.05)$.

Con relación a las tallas, el menor valor promedio y menor valor máximo se presentan en $\mathrm{BCS}$, el mayor valor promedio se observó en Oaxaca, seguido por los observados en la Isla Socorro y Jalisco. La mayor talla se observó en Isla Socorro (hembra de $95 \mathrm{~mm}$ ). En la figura 3 se presentan los histogramas de distribución de frecuencias para cada sitio de muestreo.

La densidad relativa promedio para cada Estado presenta valores similares. No obstante, en la Isla Socorro se observan dos playas (Vargas-Lozano y Blanca) con bajas densidades de caracoles por metro cuadrado, pero con los mayores valores de tallas para todos los sitios de muestreo. En contraste, en Los Frailes, BCS, se registró la más alta densidad relativa (1.24) y
Simultaneously with the collecting process and with the aim of evaluating the dye production, the dye expelling from snails was induced manually by carefully detaching the animal from the rocks, blowing over the operculum and slightly stimulating the animal foot with the thumb. The obtained dye was placed in a plastic container and it was measured afterwards. To obtain a dye yield estimate in relation to an effort measure, the time, the total number of snails and the total volume of dye were determined in each transect. The slope of the beach was determined using a clinometer.

Once the collecting was over, the total length of the snails was measured (from the apex to the end of the anterior canal). The sex of each organism was determined by observing the presence of a penis or a gonadal opening when shaking the animal to let the soft part of the organism out of the shell. Once this was accomplished, snails were liberated in the same zone from where they were taken, in wave-protected and shaded areas.

Field activities were done in all cases from 8:00 to 16:00 hours, looking for low-tide periods. The above-described procedure was done in all beaches except for the sampling sites in the coast of Oaxaca, where a trip was done together with a local fisherman who works in dyeing skeins. The number of snails needed to dye an un-dyed 285-g cotton skein were counted along with the time taken and the shore area covered by the dyer to perform this task. The biological data of the snails were recorded only at the beaches of Copal, Jicaral and San Agustín Island within the Huatulco Bays.

Moreover, interviews were held with dyers and weavers of the Pinotepa de Don Luis Mixteco community, in Oaxaca, with the purpose of determining the current use of the snail's dye in the confection of traditional clothes.

\section{Results}

\section{Population structure}

In table 1 the results of the relative abundance and the sexual proportion found are shown for each of the sampling sites considered in the Mexican Pacific coast. In general, the mean relative density is 0.86 snails $\mathrm{m}^{-2}$ (standard deviation $=0.26$ ). The highest relative density value was recorded in Los Frailes, BCS, with 1.24 snails $\mathrm{m}^{-2}$. The lowest value occurred at Bahía Blanca in the Socorro Island with 0.47 snails $\mathrm{m}^{-2}$. The sexual proportion is close to a female for every male. The Chi-square test indicates that only in Punta Pescadero, in its northern and southern parts, there are significant statistical differences to this proportion $(P<0.05)$.

In relation to the sizes, the lowest mean and the lowest maximum values were recorded in BCS, meanwhile the highest mean value was observed in Oaxaca, followed by those observed at Socorro Island and Jalisco. The largest size was 
Tabla 1. Densidad relativa, proporción sexual y tallas media, mínima, máxima y desviación estandar del caracol del tinte $P$. pansa en diversos puntos del Pacífico mexicano.

Table 1. Relative density, sexual rate and average, minimum and maximum sizes and standard deviation of the dye-snail $P$. pansa in several sites of the Mexican Pacific.

\begin{tabular}{|c|c|c|c|c|c|c|c|c|}
\hline \multirow[t]{2}{*}{ Estado } & \multirow[t]{2}{*}{ Sitio } & \multirow{2}{*}{$\begin{array}{l}\text { Densidad } \\
\text { relativa }\end{array}$} & \multicolumn{2}{|c|}{ Proporción sexual (\%) } & \multirow[t]{2}{*}{ Promedio } & \multicolumn{2}{|c|}{ Tallas (mm) } & \multirow{2}{*}{$\begin{array}{c}\text { Desviación } \\
\text { estandar }\end{array}$} \\
\hline & & & Hembras & Machos & & Min. & Max. & \\
\hline \multirow[t]{3}{*}{$\mathrm{BCS}$} & Pescadero & 0.87 & 35 & 65 & 29.7 & 19.8 & 40.0 & 3.49 \\
\hline & Pescadero (sur) & 0.66 & 38 & 62 & 23.8 & 16.0 & 37.3 & 4.62 \\
\hline & Los Frailes & 1.24 & 43 & 57 & 26.3 & 15.0 & 42.3 & 5.71 \\
\hline \multirow[t]{2}{*}{ Jalisco } & Dorada & 0.80 & 57 & 43 & 30.4 & 12.3 & 47.8 & 8.24 \\
\hline & Carrizalillos & 0.79 & 48 & 52 & 35.5 & 23.2 & 69.8 & 9.17 \\
\hline \multirow[t]{5}{*}{ Isla Socorro } & Braithwaite & 1.20 & 49 & 51 & 28.2 & 15.4 & 78.5 & 10.0 \\
\hline & Vargas-Lozano & 0.82 & 51 & 49 & 51.2 & 15.5 & 91.0 & 14.9 \\
\hline & Binners & 0.58 & 50 & 50 & 28.8 & 10.5 & 70.0 & 12.8 \\
\hline & Grayson & 0.73 & 53 & 47 & 32.1 & 15.0 & 51.0 & 8.6 \\
\hline & Blanca & 0.47 & 55 & 45 & 46.7 & 22.5 & 95.0 & 16.9 \\
\hline \multirow[t]{3}{*}{ Oaxaca } & Copal & 1.20 & n.d. & n.d. & 33.0 & 26.0 & 74.0 & 11.9 \\
\hline & Jicaral & 0.93 & n.d. & n.d. & 34.0 & 22.0 & 57.0 & 8.0 \\
\hline & Isla San Agustín & 0.64 & n.d. & n.d. & 33.5 & 23.2 & 69.8 & 6.3 \\
\hline
\end{tabular}

$*=$ ind $\mathrm{m}^{-2}$

n.d. $=$ No determinado.

un valor de la talla promedio de los caracoles bajo $(26.3 \mathrm{~mm})$, por lo que pudiera sugerirse una tendencia a que, en playas con caracoles de tallas grandes, la densidad relativa muestre valores más bajos y, por el contrario, playas con individuos de tallas pequeñas presenten valores altos de densidad. Esta tendencia se ha observado ya en varias playas de la costa de Michoacán (Álvarez, 1989).

\section{Determinación del esfuerzo y rendimientos}

En nueve de los 12 sitios considerados, se efectuó la determinación del esfuerzo y el rendimiento de tinte por área y tiempo. El número de caracoles encontrados a lo largo de cada transecto varió entre 47 y 124 caracoles $/ 100 \mathrm{~m}^{2}$, con un promedio general para los nueve sitios de 82 caracoles $/ 100 \mathrm{~m}^{2}$. El rendimiento total de tinte para cada transecto de $100 \mathrm{~m}^{2}$ presenta valores de entre 25 y $487 \mathrm{~mL} / 100 \mathrm{~m}^{2}$. De estos valores y en función del número de caracoles ordeñados, se calculó el volumen de tinte promedio obtenido de cada caracol. Este valor fue de $1.5 \mathrm{~mL} /$ caracol (tabla 2).

La talla promedio para todos los caracoles y en todas las playas fue de $33.5 \mathrm{~mm}$. Con respecto al tiempo de duración del transecto, éste fluctuó entre los 35 y los 85 min., con una duración promedio de $53 \mathrm{~min}$. La pendiente en las diferentes playas de muestreo varió entre $17^{\circ}$ y $50^{\circ}$. No se observó una relación entre la pendiente de la playa y el tiempo de duración del transecto $\left(r^{2}=0.4, P>0.05\right)$. recorded in Socorro Island (a 95-mm female). In figure 3 are shown the frequencies distribution histograms for each sampling site.

The mean relative density for each State shows similar values. Nevertheless, in Socorro Island, two beaches (VargasLozano and Blanca) show low snail densities per squared meter, but they show the highest size values of all the sampling sites. In contrast, in Los Frailes, BCS, the highest relative density was recorded (1.24) as well as a low value of the mean size of the snails $(26.3 \mathrm{~mm})$, thus suggesting a trend for relative density to exhibit lower values in beaches with big-sized snails, whereas in beaches with small-sized individuals density values are higher. This tendency has already been observed in beaches of the coast of Michoacan (Álvarez, 1989).

\section{Determination of the effort and yields}

In nine out of the twelve sites considered, the determination of the effort and the dye yield were done by area and by time. The number of snails found along each transect varied between 47 and 124 snails $/ 100 \mathrm{~m}^{2}$, with a general average for the nine sites of 82 snails $/ 100 \mathrm{~m}^{2}$. The total dye yield for each $100 \mathrm{~m}^{2}$ transect shows values between 25 and $487 \mathrm{~mL} / 100 \mathrm{~m}^{2}$. From this and in function of the number of milked snails, the average dye volume obtained from each snail was calculated in $1.5 \mathrm{~mL} /$ snail (table 2). 

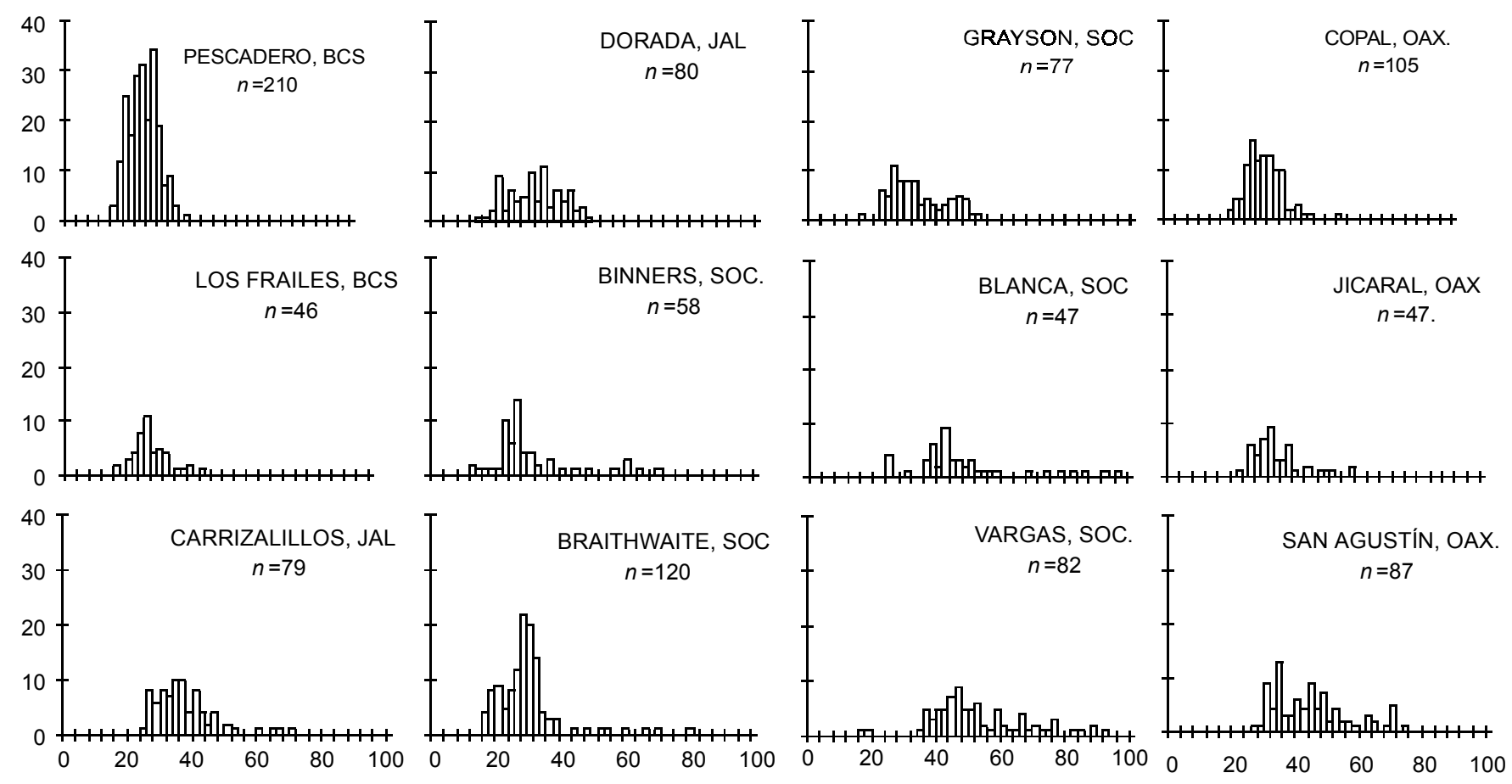

Figura 3. Histogramas de distribución de frecuencias de tallas del caracol $P$. pansa en 12 playas del Pacífico mexicano.

Figure 3. Frequencies distribution histograms for sizes of the snail $P$. pansa in 12 beaches of the Mexican Pacific.

Tabla 2. Determinación de los rendimientos de tinte en relación con el número de caracoles, talla media, tiempo de duración del transecto (minutos) y pendiente de playa (grados) para diferentes sitios del Pacífico mexicano.

Table 2. Determination of the yields of dye in relation to the number of snails, average size, time-length of the transect (minutes) and beach slope (degrees) for different sites of the Mexican Pacific.

\begin{tabular}{|c|c|c|c|c|c|c|}
\hline Sitio & $\begin{array}{l}\text { Número de } \\
\text { caracoles }\end{array}$ & $\begin{array}{l}\text { Volumen total } \\
\qquad(\mathrm{mL})\end{array}$ & $\begin{array}{l}\text { Volumen medio } \\
\qquad(\mathrm{mL})\end{array}$ & $\begin{array}{l}\text { Talla media } \\
\qquad(\mathrm{mm})\end{array}$ & $\begin{array}{l}\text { Pendiente } \\
\text { de playa }\end{array}$ & $\begin{array}{c}\text { Tiempo de } \\
\text { transecto }\end{array}$ \\
\hline Los Frailes & 124 & 50.0 & 0.4 & 26.3 & 18 & 60 \\
\hline Pescadero & 66 & 25.0 & 0.4 & 23.0 & 20 & 50 \\
\hline Dorada & 80 & 35.0 & 0.4 & 30.4 & 17 & 35 \\
\hline Carrizalillos & 79 & 64.0 & 0.8 & 35.5 & 20 & 55 \\
\hline Braithwaite & 120 & 69.9 & 0.5 & 28.2 & 25 & 55 \\
\hline Vargas & 82 & 487.7 & 5.9 & 51.2 & 50 & 85 \\
\hline Binners & 58 & 78.8 & 1.3 & 28.8 & 20 & 50 \\
\hline Grayson & 77 & 48.8 & 0.7 & 32.1 & 48 & 50 \\
\hline Blanca & 47 & 160.7 & 3.4 & 46.7 & 17 & 40 \\
\hline Promedio & 81 & 113.3 & 1.5 & 33.5 & 26 & 53 \\
\hline
\end{tabular}

Relación talla promedio-volumen de tinte

En la figura 4a se presenta la relación observada entre la longitud media de los caracoles en cada sitio y el volumen promedio de tinte obtenido. Asimismo, en la figura $4 \mathrm{~b}$ se muestra la relación entre longitud media y volumen total de tinte por
The average size for all the snails and in all the beaches was $33.5 \mathrm{~mm}$. In regard of the time spent on the transect, this fluctuated between 35 and 85 min., with an average time of 53 $\mathrm{min}$. The slope in the different beaches varied between $17^{\circ}$ and $50^{\circ}$. No relations were observed between the time elapsed in the transect and the slope of the beach $\left(r^{2}=0.4, P>0.05\right)$. 
transecto. En ambos casos se da un buen ajuste a la regresión potencial con un valor de $r^{2}$ cercano a $0.8(P<<0.01)$.

\section{Rendimiento del tinte sobre madejas}

A partir del recorrido realizado en noviembre de 1998, acompañando a un teñidor mixteco, por áreas rocosas de las Bahías de Huatulco, Oaxaca, se necesitaron 921 caracoles con una talla promedio de $37.3 \mathrm{~mm}$, para teñir una madeja de algodón de $285 \mathrm{~g}$ de peso. Se ordeñaron caracoles en cinco sitios de las bahías, con un tiempo total de 1015 minutos en una distancia de línea de costa estimada en $1300 \mathrm{~m}$.

Estos datos sugieren que una persona puede llegar a teñir aproximadamente dos madejas por semana de trabajo y que se requiere de 1.251 de tinte aproximadamente para teñir cada madeja. Por lo tanto, a partir de estos datos, las estimaciones indican que se podrían obtener cerca de 2.51 de tinte por persona/semana.

\section{Uso actual del tinte del caracol}

De las entrevistas realizadas a teñidores y tejedoras mixtecos de la población de Pinotepa de Don Luis, Oaxaca, en noviembre de 1998, se obtuvieron algunos datos pertinentes. Las actividades de tinción se realizan cada año de octubre a marzo. Esta temporada se inicia al término de la época de ciclones y termina hasta marzo, o aún antes, y corresponde a una época en que los caracoles en la costa de Oaxaca no se encuentran en su período reproductivo. La asociación de teñidores, previa reunión, determina la formación de grupos de teñidores y sus fechas de tinción. Estas personas recogen madejas de algodón de entre las tejedoras del pueblo, las cuales son teñidas por encargo, además de teñir las de su familia. Las madejas son de algodón trenzado y las que se utilizan actualmente son de marca comercial. Las madejas tienen un peso promedio de $285 \mathrm{~g}$.

Actualmente 25 personas se agrupan en una Cooperativa de Teñidores de Pinotepa de Don Luis, Oaxaca. Sin embargo, no todos los años participa el total de los miembros en la tinción. Se forman grupos de 3 personas, en promedio, los cuales recorren la costa rocosa cercana a las Bahías de Huatulco, en una o dos semanas al mes, esto dependiendo del número de madejas a teñir y el número de teñidores que forman el grupo. Se tiñen alrededor de 15 madejas al mes y 60 madejas al año.

\section{Discusión}

A partir de estos resultados es posible hacer una serie de inferencias. Se supone que dado el régimen de mareas, es posible realizar actividades de recolecta de caracoles y extracción de tinte por cuatro horas al día, durante cinco días a la semana. Si se considera un tiempo promedio de 53 minutos por cada 50 $\mathrm{m}$ lineales de costa rocosa, entonces sería posible recorrer una distancia aproximada de $250 \mathrm{~m} /$ día o 1,250 m/semana.

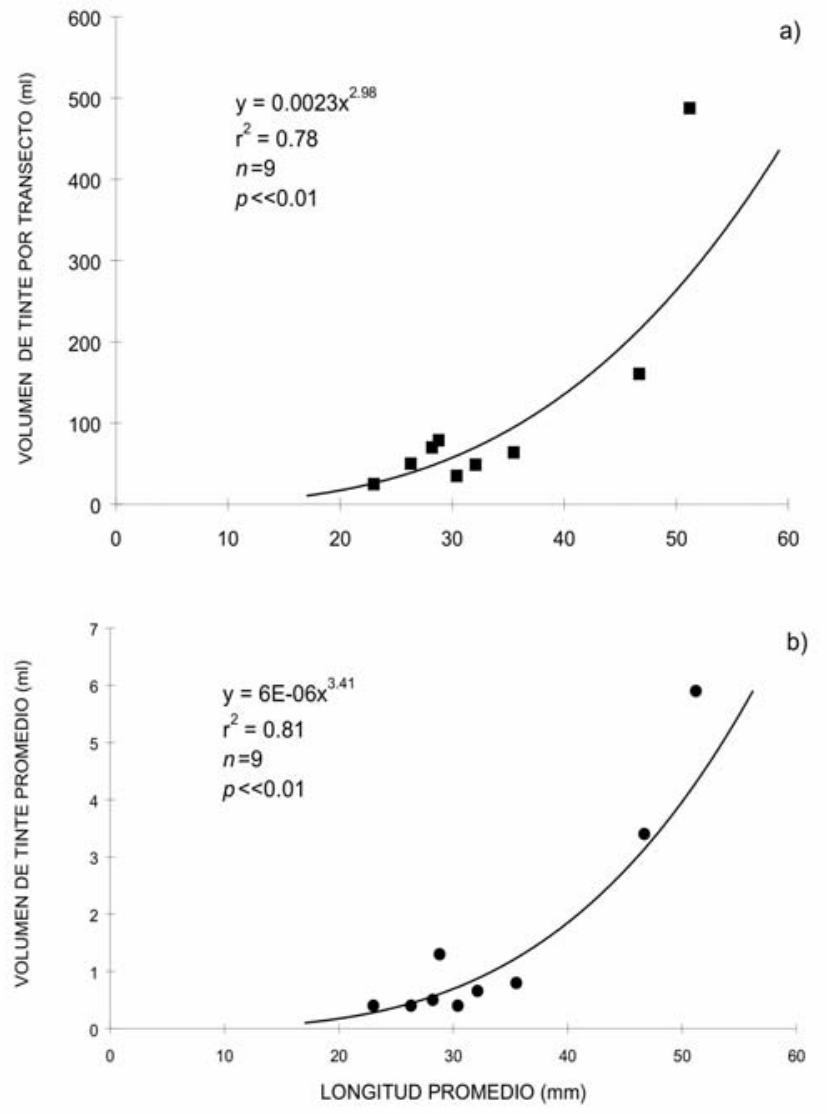

Figura 4. (a) Relación entre la longitud media de los caracoles y el volumen medio de tinte por playa y (b) relación entre la longitud media de los caracoles y el volumen total de tinte por transecto.

Figure 4. (a) Relation between the average length of the snails and the average volume of dye by beach and (b) relation between the average length of the snails and the total volume of dye by transect.

\section{Mean size-dye volume relation}

The relation observed between the average snail length in each site and the average volume of dye obtained is shown in figure $4 \mathrm{a}$. In the same manner, the relation between the average length and the total dye volume by transect is shown in figure $4 \mathrm{~b}$. There is a good fit to the regression with an $r^{2}$ value close to $0.8(P<<0.01)$.

\section{Dye yield on skeins}

From the trip done in November 1998 together with a Mixteco dyer over rocky areas of the Huatulco Bays, Oaxaca, 921 snails with a 37.3-mm average size were needed to dye a 285 -g cotton skein. Snails were milked in five sites of the bays spending a total of 1015 minutes in a distance along the shore estimated in $1300 \mathrm{~m}$. 
Tabla 3. Estimaciones de la densidad relativa y proporción sexual realizadas por diferentes autores, en varios estados del Pacífico mexicano.

Table 3. Estimations of the relative density and sexual rate done by different authors in several states of the Mexican Pacific.

\begin{tabular}{lcccc}
\hline Estado & \multirow{2}{*}{$\begin{array}{c}\text { Densidad relativa } \\
\text { (ind m }{ }^{-2} \text { ) }\end{array}$} & \multicolumn{2}{c}{ Proporción sexual } & Fuente \\
\cline { 3 - 4 } & 1.14 & Hembras & Machos & \\
\hline Sinaloa & 2.27 & 1.0 & 0.7 & Enciso et al. (1998) \\
Nayarit & 1.60 & 1.0 & 1.3 & Acevedo et al. (1990) \\
Jalisco & 1.14 & 1.0 & 0.7 & Reyes-Aguilera (1993) \\
& 1.7 & 1.0 & 0.7 & Michel-Morfín et al. (2000) \\
& 0.88 & 1.0 & 1.3 & Álvarez (1989) \\
Michoacán & 0.74 & 1.0 & 0.8 & Turok et al. (1988) \\
Oaxaca & & & &
\end{tabular}

Con la estimación del tiempo y la distancia recorrida y considerando un promedio de 82 caracoles cada 53 minutos, sería posible ordeñar 370 caracoles/día/persona o 1850 caracoles/ semana/persona. Esto conllevaría una estimación de $2770 \mathrm{~mL}$ de tinte/semana/persona (considerando un volumen medio de $1.5 \mathrm{~mL} / \mathrm{caracol})$. Pese a ser éstas estimaciones lineales simples, permiten una aproximación al rendimiento esperado.

Las estructuras de tallas observadas a lo largo de los cuatro estados del Pacífico mexicano denotan un aumento en las tallas promedio hacia el sur. Esto es, en Oaxaca e Isla Socorro se observan las mayores tallas promedio e individuales. Esto pudiera tener relación con la afinidad biogeográfica tropical de la especie, por lo tanto las abundancias y tallas serían mayores hacia el centro de su distribución geográfica. Sin embargo, es necesario realizar estudios de edad, crecimiento y mortalidad por regiones para determinar este aspecto.

Además, consistentemente se observó en todas las playas de muestreo, que las hembras presentan tallas mayores en promedio que los machos y que la proporción sexual de las poblaciones en su estado natural es cercana a un macho por cada hembra. Esto tiene implicaciones importantes en la definición de las estrategias de explotación de la especie ya que, por una parte denota un crecimiento diferencial entre los sexos, tal y como lo refieren Michel-Morfín et al. (2000), y por otra parte, el rendimiento de tinte será mayor en sitios con presencia de individuos de tallas mayores a los $50 \mathrm{~mm}$, en función de la relación potencial que se establece entre la longitud promedio de los caracoles y el volumen de tinte obtenido.

Las densidades relativas y proporciones sexuales observadas en los sitios de muestreo considerados en este trabajo presentan valores medios similares a los observados en varios estados de la costa del Pacífico (tabla 3). Estas densidades y las tallas observadas, pueden ser un indicador de que las poblaciones de Oaxaca se han recuperado del período de sobrexplotación, aún cuando no existan estimaciones previas a 1988.

En todos los estudios referidos se utilizó el mismo tipo de muestreo basado en transectos lineales en la zona intermareal
These data suggest that a person could dye approximately two skeins per working week and that approximately $1.25 \mathrm{~L}$ of dye are required to dye each skein. Therefore, estimates from these data indicate that nearly $2.51 \mathrm{~L}$ of dye could be obtained per person per week.

Current use of the snail's dye

From the interviews held with the Mixteco dyers and weavers from Pinotepa de Don Luis in November 1998, some pertinent data were obtained. The dyeing activities are carried out from October to March. This season starts at the end of the cyclon season and finishes until March or even before and belongs to a period where the snails in Oaxaca are not in their reproductive cycle. In a previous meeting, the dyers' association determines the formation of groups of dyers and their dyeing dates. Dyers collect cotton skeins among the local weavers, which are dyed by agreement along with those weaved by their own family. Skeins are intertwined cottonmade and those currently used are from a commercial brand. Skeins have an average weight of $285 \mathrm{~g}$.

Currently, 25 dyer-people from Pinotepa de Don Luis Oaxaca are joined in a cooperative. However, not all of them participate each year in the dyeing process. In average, 3people groups are formed which cover the rocky shore close to the Huatulco Bays during one or two weeks a month, this depending on the number of skeins to be dyed and the number of dyers that form the group. About 15 skeins are dyed per month and 60 skeins per year.

\section{Discussion}

A series of inferences can be made from these results. Supposedly, given the tidal regime, it is possible to collect snails and extract dye four hours a day during five days a week. If an 
rocosa, por lo que esos resultados pueden ser comparables con los presentes y, por lo tanto, ofrecen en conjunto un adecuado panorama de la estructura y rendimientos potenciales de las poblaciones del caracol en el Pacífico mexicano. Durante estos muestreos se han considerado diferentes tipos de costa rocosa y grado de exposición al oleaje, con los consecuentes cambios en las condiciones fisiográficas, por lo que se considera que se tiene bien cubierta la variabilidad ambiental de las playas donde se presenta el caracol. Esto permite concluir que el caracol P. pansa es una especie bien representada en el litoral del Pacífico mexicano y, por sus abundancias, es susceptible de ser aprovechada.

Por otro lado, con excepción de los puntos considerados en Isla Socorro, donde el efecto antropogénico sobre las poblaciones es virtualmente nulo dadas las condiciones de lejanía y restricciones de acceso a la isla, en las demás playas cabría valorar la posibilidad de que exista un efecto variable de la pesca incidental de moluscos comestibles en la zona intermareal sobre la densidad y proporción sexual del caracol. Esta consideración se hace en función de que los individuos de tallas mayores, con mayores posibilidades de ser hembras, serían más apreciados y buscados como alimento por los pescadores.

De aquí la importancia de contar con estimaciones realizadas sobre poblaciones silvestres con escaso o nulo impacto, como las de Isla Socorro, a fin de comparar con poblaciones de la costa continental del Pacífico mexicano, sobre todo en el caso de que a futuro se establezca una actividad pesquera en torno a la extracción del tinte del caracol. Zonas insulares o continentales de acceso restringido, podrían constituir un punto de referencia muy importante para evaluar el impacto del uso de este caracol, además de constituir zonas de reserva de la variabilidad genética.

Con respecto a los rendimientos de tinte, tanto de manera individual como por unidad de área y tiempo, conviene tomar en cuenta la posibilidad de un error inherente a la forma de ordeña del caracol. Esto es, una fracción del volumen considerado como tinte, pudiera corresponder al agua presente en la cavidad del manto y que es expulsada junto con el tinte al momento de estimular al caracol, pero cuyo volumen estaría en relación a la talla del caracol, o bien, agua que se incorpora a partir de la alta humectación que se tiene en la zona de rompientes.

De cualquier manera, aunque pudiese haber sobrestimación, la relación potencial entre la talla de los caracoles y el volumen de tinte se observa en ambas estimaciones. Mas aún, de presentarse la tinción directa sobre madejas de hilo de algodón u algún otro material, la incorporación de agua pudiera hasta cierto punto aumentar el rendimiento, como lo sugieren Michel-Morfín et al. (en prensa), quienes probaron diferentes proporciones tinte:agua.

Las estimaciones que se presentan para el rendimiento de tinte por persona/área/semana, serán de utilidad para average time of 53 minutes is considered by every 50 linear $\mathrm{m}$ of rocky shore, then it would be possible to cover an approximate distance of $250 \mathrm{~m} /$ day or $1,250 \mathrm{~m} /$ week.

With the estimation of the time and distance covered and considering an average of 82 snails every 53 minutes, milking 370 snails/day/person or 1850 snails/week/person would be possible. This would lead to an estimate of $2770 \mathrm{~mL}$ of dye/ week/person (considering a mean dye volume of $1.5 \mathrm{~mL} / \mathrm{snail}$ ). In spite of being simple linear estimations, these allow an approach to the expected yield.

The observed size-structure along the four States of the Mexican Pacific denotes an increase in average sizes towards the South. This is, in Oaxaca and the Socorro Island the highest average and individual sizes are observed. This would be related to the tropical biogeographical affinity of this species, therefore the abundances and sizes would be higher towards the center of its geographical distribution. However, in order to determine this fact, it is necessary to perform studies about the age, growth and mortality by regions.

Moreover, it was consistently observed in all the sampled beaches that females show, in average, higher sizes than males and that the sexual proportion of the populations in its natural state is close to one male by every female. This has important implications in the definition of exploitation strategies for this species since, in a way, it denotes a differential growth between sexes as is referred by Michel-Morfín et al. (2000) and, in another, the dye yield would be higher in sites with individuals longer than $50 \mathrm{~mm}$, in function of the potential relationship that is established between the mean length of the snails and the volume of dye obtained.

The relative densities and the sexual proportions observed in the sampling sites considered in this work have mean values similar to those observed in several states of the Pacific coast (table 3). These densities and the sizes observed can indicate that the populations in Oaxaca have recovered from the exploitation period, even when there are no estimations before 1988.

In all the referred studies the same kind of sampling was used based on linear transects in the rocky intertidal zone, so their results are comparable to ours and therefore together they offer an adequate reference of the structure and potential yields of snail populations in the Mexican Pacific. Different kinds of rocky shores and degrees of wave-exposures, with their consequent changes in the physiographic conditions have been considered in these samplings as well as it is considered that the environmental variability of the beaches where there are snails has been appropriately covered. This allows us to conclude that the snail P. pansa is a well-represented species in the Mexican Pacific littoral and, due to its abundance, it is susceptible to be used.

On the other hand, except for the spots considered at Socorro Island, where the anthropogenic effect on populations is virtually null given the conditions of farness and access 
determinar si la actividad de extracción del tinte del caracol puede constituir una opción viable de uso comercial de la especie, sobre todo al no estar disponible la información histórica sobre la pesquería que se estableció inicialmente en el estado de Oaxaca en 1984 y que se extendió posteriormente a Michoacán, Jalisco y Colima hasta su veda total en 1988. La poca información existente indica que fue una actividad altamente rentable para los concesionarios de los permisos e incluso para los pescadores que realizaban la extracción del tinte (Turok et al., 1988; Castillo-Rodríguez y AmezcuaLinares, 1992), lo que es confirmado por los mismos pescadores entrevistados recientemente en Jalisco. Estos datos pueden ser utilizados para el desarrollo de un modelo de la pesquería, a partir del cual se evalúe la factibilidad de explotación y las estrategias de manejo.

La adecuada definición de las estrategias de manejo, puede dar lugar a la utilización de un importante y valioso recurso ancestral, como lo es el colorante púrpura, dentro de un contexto en el que se respete la riqueza y el legado cultural de la tradición del teñido con colorantes naturales que se ha desarrollado en la costa del Pacífico mexicano.

\section{Agradecimientos}

Agradecemos a Habacuc Avendaño, de la Cooperativa de Teñidores de Pinotepa de Don Luis, Oaxaca, por su valiosa información, así como a Marte Gil de León y Alejandro Estrada, por su ayuda durante el trabajo en Oaxaca; a Daniel Kosonoy y a Víctor Landa por su apoyo en el trabajo en Isla Socorro y Jalisco; y al personal de la Secretaría de Marina por su apoyo en los muestreos en Isla Socorro. Agradecemos también a los revisores anónimos por sus valiosas aportaciones al trabajo. E. A. Chávez es becario de la COFAA-IPN.

\section{Referencias}

Acevedo, J. (1995). Aprovechamiento del tinte de Purpura pansa en el Pacífico Mexicano. Informe. CRIP-Patzcuaro, INPSEMARNAP, México, $22 \mathrm{pp}$.

Acevedo, J. y Hernández, C. (1988). Aspectos poblacionales y etnobiológicos del caracol Purpura pansa Gould, 1853 en la costa de Oaxaca. Tesis Profesional, Lic. en Biología, Fac. de Ciencias, UNAM, $146 \mathrm{pp}$.

Acevedo, J., Escalante, M. y López, C. (1990). Aspectos poblacionales del caracol del tinte Purpura pansa Gould, 1853, en las costas de Nayarit. Inter UAS, 1(1): $18-22$.

Álvarez, A. (1989). Relaciones ecológicas y algunos aspectos poblacionales del caracol Purpura pansa Gould, 1853 en la costa del estado de Michoacán, México. Tesis Profesional, Lic. en Biología, Univ. Michoacana San Nicolás de Hidalgo, 126 pp.

Anónimo (1988). Acuerdo Intersecretarial, entre las Secretarías de Pesca, Educación Pública, y Desarrollo Urbano y Ecología, con el que se regula el desarrollo, conservación y aprovechamiento del caracol Purpura pansa, beneficiando a los núcleos de población que tradicionalmente lo han explotado. México, D.F. 13 de Marzo de 1988. restrictions to the island, in the rest of the beaches the possibility of a variable effect of edible mollusk incidental fishing ought to be assessed on the density and sexual proportion in the snails of the intertidal zone. This consideration is made given that greater individuals, with a high probability of being females, would be more appreciated and searched as food by fishermen.

That is why it is important to have estimations done on wild populations with scarce or null impact as those in Socorro Island, in order to compare them with populations from the west coast of the Mexican Pacific, especially in the case of a future commercial fishing activity for the extraction of the snail's dye. Insular or continental zones with a restricted access could be an important reference point to evaluate the impact of the use of this snail, besides constituting reserve zones for the genetic variability.

In respect of the dye yields, either individually as by unit area and time, it would be convenient to take into consideration the possibility of an inherent error in the way of milking the snail. This is, a fraction of the volume considered as dye, could be water present in the mantle cavity which is expelled together with the dye at the moment of stimulating the snail, but which volume would be in relation to the snail size or, water that incorporates due to high moisture levels in the breaker zone.

Anyhow, even in the case of overestimation, the potential relation between snail size and dye volume is observed in both estimations. Furthermore, if the direct dying on cotton-thread skeins or any other material would occur, the incorporation of water would increase the yield, as is suggested by MichelMorfín et al. (in press) who tested different dye:water proportions.

The dye yield estimations per person/area/week obtained would be useful to determine whether the snail dye extraction activity could be a viable option for the commercial use of this species, especially when there is an important lack of historic information of this fishery that was established in Oaxaca in 1984 and extended to Michoacan, Jalisco and Colima until its total ban in 1988. The few information available indicates that it was a highly profitable activity for both, the license holders and the fishermen that performed the dye extraction (Turok et al., 1988; Castillo-Rodríguez and Amezcua-Linares, 1992), which is confirmed by the recently interviewed fishermen in Jalisco. These data could be used for the development of a fishery model, from which the feasibility of exploitation and the management strategies could be assessed.

The adequate definition of fishery management strategies would lead to the use of an important and valuable ancient resource, as is the purple dye, within a context of respect to the richness and cultural legacy of the traditional use of natural dyes that has been developed in the coast of the Mexican Pacific. 
Anónimo (1994). Norma Oficial Mexicana NOM-059-ECOL-1994, que determina las especies y subespecies de flora y fauna silvestres terrestres y acuáticas en peligro de extinción, amenazadas, raras y las sujetas a protección especial, y que establece especificaciones para su protección. Diario Oficial de la Federación, 16 de Mayo de 1994.

Avilés, A., Muciño, M. y Peña, I. (1990). Sinopsis de la biología del caracol púrpura del Pacífico. Instituto Nacional de la Pesca. Serie: Documentos de Trabajo, Año II. No. 24. 10 pp.

Castillo-Rodríguez, Z.G. y Amezcua-Linares, F. (1992) Biología y aprovechamiento del caracol morado Plicopurpura pansa (Gould, 1853) (Gastropoda: Neogastropoda) en la costa de Oaxaca, México. An. Inst. Cienc. del Mar y Limnol. UNAM, 19(2): 223234.

Enciso, C., Rámirez, V.M., Tirado, A.R. y Vallarta, A. (1998). Evaluación de la población y épocas de reproducción del caracol Purpura pansa (Gould, 1853) en Mazatlán, Sinaloa, México. Tesis profesional, Lic. en Biología Pesquera, Universidad Autónoma de Sinaloa, 56 pp.

Fonseca, M.J (1998). Algunos aspectos de dinámica poblacional del caracol púrpura Plicopurpura patula pansa (Gould, 1853) en una playa rocosa de Yelapa, Bahía de Banderas, Jalisco (febrero a julio de 1997). Tesis Profesional, Lic. en Biología, División de Ciencias Biológicas y Ambientales, Univ. de Guadalajara. 43 pp.

Holguín, O. (1993). Distribución, abundancia y composición pesotalla de Purpura pansa (Mollusca - Gastropoda) en Isla Socorro, Archipiélago Revillagigedo, México. Zoología Informa 25: 24 33.

Keen, M. (1971). Sea shells of Tropical West America. Stanford University Press, Stanford, California, 1064 pp.

León-Alvarez, H. (1989). Estructura poblacional, producción y tiempo de recuperación del tinte de Purpura pansa Gould, 1853 (Gastropoda: thaididae) en algunas playas rocosas de la Bahía de Cuastecomate, San Patricio Melaque, Jalisco, México. Tesis Profesional, Lic. en Biología, Fac. de Ciencias, Univ. de Guadalajara, $107 \mathrm{pp}$.

Michel-Morfín, J.E. (2000). Ecología y aprovechamiento del caracol del tinte Plicopurpura pansa en las costas del Pacífico mexicano. Tesis de Doctorado en Ciencias Marinas, CICIMAR-IPN, 134 pp.

Michel-Morfín, J.E., Chávez, E.A. and Landa, V. (2000). Population parameters and dye yield of the purple snail Plicopurpura pansa

\section{Acknowledgements}

We thank Habacuc Avendaño from the dyers cooperative of Pinotepa de Don Luis, Oaxaca, for his valuable information, as well as Marte Gil de León and Alejandro Estrada for their help in Oaxaca; to Daniel Kosonoy and Víctor Landa for their support in Socorro Island and Jalisco and the Secretaría de Marina staff for their help with the Socorro Island samples. We also thank the anonymous reviewers for their valuable suggestions. E.A. Chávez has a scholarship from the COFAA-IPN.

English translation by Adrián R. López-González.

(Gould, 1853) of West central México. J. Shellfish Res. 19(2): 919-925.

Michel-Morfín, J.E. and Chávez, E.A. (2000). Effect of repetitive dye extraction over yield and survival rate of the purple snail Plicopurpura pansa (Gould, 1853). J. Shellfish Res. 19(2): 913917.

Michel-Morfín, J.E., Reyes-Aguilera, S., Landa J.V. y Ríos-Jara, E. (en prensa). Aspectos relativos al rendimiento y foto-oxidación del tinte del caracol púrpura Plicopurpura pansa (Gould, 1853). Oceanología.

Reyes-Aguilera, S. (1993). Estimación poblacional, producción, fotooxidación y rendimiento del tinte del caracol Purpura pansa (Gould, 1853) de la zona sur del litoral rocoso de Jalisco. Tesis Profesional, Lic. en Biología, Fac. de Ciencias Biológicas, Univ. de Guadalajara, $115 \mathrm{pp}$.

Ríos-Jara, E., León, H., Lizárraga-Chávez, L. y Michel-Morfin, E. (1994). Producción y tiempo de recuperación del tinte de Plicopurpura patula pansa (Neogastropoda: Muricidae) en Jalisco, México. Rev. Biol. Trop., 42(3): 537-545.

Turok, M. (1996). Xiuhquilitl, nocheztli y Tixinda. Tintes del México antiguo. Arqueología Mexicana 12: 26-33.

Turok, M., Sigler, A.M., Hernández, E., Acevedo, J., Lara, R. y Turcott, V. (1988). El caracol Purpura una tradición milenaria en Oaxaca. Dirección General de Culturas Populares, SEP, México, $166 \mathrm{pp}$. 